\author{
Rafał Dowgier
}

University of Bialystok

\title{
THE PURPOSIVE INTERPRETATION OF POLISH TAX LAW
}

\begin{abstract}
The results of the linguistic interpretation should be verified through systemic and purposive methods of interpretation. That process is especially desirable in the cases where the result of the linguistic interpretation is not unequivocal. Whereas, as practice demonstrates, the quality of tax law is not the best, it is impossible to overestimate the role of the non-linguistic method of interpretation. The object of this paper was to present the role which the linguistic interpretation may play in interpreting the tax law. However it was also important to: place the purposive interpretation among the methods of tax law interpretation and to present static and dynamic elements in tax law interpretation. Within the frames of this paper one can find out about historical interpretation of tax law, economic method of tax law interpretation and purposive interpretation directives. The above considerations allow for posit a thesis according to which purposive interpretation is an indispensable element of the process of interpreting a legal text. Its role in the scope of norms of tax law is, however, peculiar, since it serves only to verify the results of linguistic interpretation. However, it can be indicated that the growth in importance of purposive interpretation is direct proportional to the fall in the quality of tax law regulations.
\end{abstract}

\section{General remarks}

The derivative concept of law interpretation expressed in the legal maxim interpretatio cessat in claris, means the proposition of employing any possible interpretative methods seeking a full clarity as to the substance of a legal norm. At this assumption the results of the linguistic interpretation are verified through other methods of interpretation: systemic and purposive. Application of these methods is especially desirable in the cases where the result of the linguistic interpretation is not unequivocal. Whereas, as practice demonstrates, the quality of tax law is not the best, it is impossible to overestimate the role of the non-linguistic method of inter- 


\section{Rafat Dowgier}

pretation. The object of this paper is to present the role which the linguistic interpretation may play in interpreting the legal texts which are the sources of tax law.

Purposive interpretation constitutes a particular type of functional interpretation. It involves an attempt at reading the meaning of a legal provision taking into consideration the aim of the legislator making it. Law is, after all, not only a certain form but also a substance, which is sometimes called a spirit of law: ratio est anima legis. Assuming that it is an instrument of purposive organising social relations, when establishing its meaning we cannot restrict ourselves to examining the form only, but we also, or even foremost, take into consideration its meaning, i.e. the objective or rather objectives which a given regulation is supposed to achieve. (Smoktunowicz, Mieszkowski, 1998, p. 78). What intentions accompanied the legislator while creating a particular regulation may be seen in such elements of a normative act as its title or preamble (if there is one), or else non-normative elements, such as, for example: transcripts of parliamentary work proceedings on an act of law, or also a justification of the bill. If we can determine the purpose of the regulation analysed, we can interpret it correctly, for adopting the assumption of the comprehensiveness of tax law interpretation, the correctness of this process is dubious. However, the issue of mutual relations between the purposive interpretation on the one part and systemic and linguistic interpretations on the other is understood differently in judicial practice and doctrine.

\section{The place of purposive interpretation among the methods of tax law interpretation}

It is beyond question that purposive interpretation in tax law should be applied in strict connection with linguistic and systemic interpretation. The problem is if it is expected only to eliminate interpretative doubts connected with the vagueness of a legal text and eliminate any other ambiguities, or else it may also be used for correcting the results of a linguistic interpretation? Opinions on this subject matter are split. Legal decisions of the Supreme Administrative Court (Naczelny Sąd Administracyjny, NSA) point out that purposive interpretation as an auxiliary tax law method of decoding the substance of legal provisions, may and should be applied only exceptionally, when in view of the acceptable semantic rules of an ethnic linguistic the sense of legal rules is ambiguous. In its statement of reasons for another decision NSA stated that a purposive interpretation cannot cancel a linguis- 
tic interpretation. Also the Constitutional Tribunal (hereinafter referred to Trybunal Konstytucyjny, TK) decided in its statement of reasons for the wyrok TK z 20 lutego 1991 (W. 5/90), that since the linguistic and logical interpretation lead to a particular conclusion, and this conclusion does not result in unacceptable solutions, there are no grounds for using a purposive interpretation. The aforesaid implies that purposive interpretation is exceptional and is acceptable only if the linguistic method leaves us with doubts, but even then it cannot lead to results contradictory to this method of interpretation. Nevertheless, against this seemingly unequivocal standpoint, we can propose a thesis that purposive interpretation is acceptable also when the text is unequivocal, which, in extreme situations, may result in purposive interpretation giving legal texts the meaning which is far from their linguistic meaning. (Gizbert-Studnicki, 1996). This position is justified by a clear move of the interpretation limits from "the sound of the law wording" towards "the possible sense of the law wording". In the field of tax law, where the text of a normative act plays a special role in the context of the principle of legal certainty, the cases whose meaning by a purposive interpretation differs considerably from the linguistic meaning will be rather rare, which does not mean that they will cease to occur. Such a situation may be especially encountered when the application of the linguistic interpretation may lead to ignoring provisions of law. On the other hand, the process of purposive interpretation should be recognised as fully justified in any case, which was demonstrated by the statement of NSA (wyrok NSA z 23 czerwca 1983, II SA 535/83) pointed out in (Smoktunowicz, Mieszkowski, 1998, p. 80), which stated that the organ of state administration is obligated to pursue the purpose of the act of law and general rules included foremost in Article 7 of the Administrative Proceeding Code (ustawa z dnia 14 czerwca 1960 r. - Kodeks postępowania administracyjnego (Dz. U. z 2013, poz. 267 j.t.)). Furthermore, in the statement of reasons of the statement of NSA (wyrok NSA z dnia 6 listopada 1996, SA/Ka 1895/95) this Court argued that the interpretation error may involve the isolation of the analysis of the provision referred to as a basis for the decision from the provisions of the act which determine the tax subject (...) as well as failing to assess what end the provision was supposed to serve.

Taking into consideration the aforementioned output of judicial decisions, it is important to note that the literature underscores that the applicable interpretation methods can be put into a certain formula, which has a form of algorithm, where the starting point is linguistic interpretation. (Brzeziński, 2008). Regardless of its results, which could be unequivocal or ambiguous, it is necessary to apply non-linguistic methods. Purposive in- 


\section{Rafat Dowgier}

terpretation allows to find the sense of a legal text through giving it such a meaning, with which it would have the best axiological justification in the adopted system of values. (Mastalski, 1998, p. 97).

The application of purposive interpretation is connected, however, with a certain danger connected with a too far-going discretion of the entity applying the law in pursuing the purpose of an act of law. As a result, the adopted aim of a particular regulation may not reflect the will of the legislator but exclusively meet the interpreter's expectations or express his particular interests. In tax law this danger may manifest itself in the administration organs, and even courts, applying purposive interpretation inclining towards the interest of taxing authorities, pursuing the interpretation in dubio pro fisco. ${ }^{1}$ There are, however, certain 'safety devices', which are expected to prevent such situations occurring. First of all, it is important to note the rule of the statutory regulation of tax matters in Article 214 of the Constitution of the Republic of Poland (Konstytucja Rzeczpospolitej Polskiej z dnia 2 kwietnia 1997 (Dz. U. z 1997 Nr 78, poz. 483)). The constant qualities of tax named in this provision, such as subject and object of taxation as well as tax rates, as expressis vebis in the act of law, will not be subject to purposive interpretation, since they should be interpreted precisely.

The decision of the Supreme Court (wyrok Sądu Najwyższego z 22 października 1992, III ARN 50/92) expressed the view according to which "the fundamental rule of tax law in a democratic state ruled by law is that the range of the subject of taxation must be precisely determined in the Act of Taxation, and the interpretation of its provisions cannot be extensive."

Another protection may be the rule, accepted on the grounds of tax law, that doubts cannot be interpreted to the detriment of the taxpayer. Thus, if a provision is linguistically questionable, it is possible to seek its meaning by means of purposive interpretation. However, it is not allowed to extend the range of taxation. This type of reasoning has been raised in the literature to the rule of tax law, according to which doubts should be resolved in favour of the taxpayer. (Mariański, 2009). It is even proposed to establish this rule explicite in general provisions of tax law. (Mariański, 2009, p. 243).

\section{Static and dynamic elements in tax law interpretation}

When searching for a purpose in law it is necessary to pose a question from whose point of view this purpose should be determined. Should it be 
looked at from the perspective of the historic legislator creating a particular act or should we take an attempt at "updating" the approach, i.e. take into consideration the changes which have occurred since the day of its origins until the moment of interpretation? This dilemma may be reduced to the choice of one of the conceptions of interpretation: static (subjective), which assumes that the change of social relations should have no bearings on the results of the law interpretation, or dynamic (objective) based on the assumption that the change of socio-economic relations allows us, with the course of time, to change the interpretation of the provisions of the act. To grasp an essence of the problem, it is worth distinguishing the purpose of the legislator from the purpose of the act of law. B. Brzeziński introduces such a distinction (Brzeziński, 2001, p. 164). The aim of the legislator remains basically unchanged regardless of the circumstances and cannot be corrected. This means that a norm once established by means of a rule of law is not changed until the time when the legislator himself repeals (changes) it: the static interpretation. Furthermore, the purpose of the act of law may evolve, which means that it should be read through the prism of current needs and requirements expected from the law: the dynamic interpretation. Both types of interpretation have their advantages and disadvantages. The static interpretation is desirable from the point of view of the stability of the binding norms and legal security (certainty of law). On the other hand, the dynamic interpretation does not guarantee such a certainty but may prevent the law from petrifaction and its anachronistic interpretation.

Bearing in mind the specificity of tax law, where the principle of security and certainty of law is emphasised, it could seem that it would make more sense to adopt the static theory of interpretation. However, it is important to underscore a certain drawback of this assumption, which results from the fact that through fast-changing social and economic relations as well as the excessive length of legislative procedures, the law would lose its value. Granting only the legislator the title to changes and adjustment of legal regulations, we expose ourselves to the dissonance between law and life. Therefore, to some extent it seems necessary to reach the dynamic theory of interpretation, which allows us to "go along with the spirit of time". ${ }^{2}$ It seems justified to argue that the interpretation of tax law should be a compromise between one and the other theory. Especially the static theory is applicable in reference to the regulations imposing tax obligations, whereas the dynamic interpretation will apply to the provisions concerning tax reliefs and exemptions. (Smoktunowicz, Mieszkowski, 1998, p. 124). 


\section{Rafat Dowgier}

\section{Historical interpretation of tax law}

The so-called historical interpretation should be recognised as a special type of interpretation, which is connected with the notion of purpose. ${ }^{3}$ It should not be confused with the static theory of interpretation, which is sometimes also referred to as historical. The essence of historical interpretation, which is discussed here, is searching for arguments for a certain meaning of the provision of law on the basis of the changes in the given legal regulation as well as differences between the original and subsequent wording of the provision. The starting point is establishing the legislator's purpose creating a particular regulation in the past (static interpretation), determining the purpose of the regulation itself (dynamic interpretation), as well as the reasons which made the legislator change its substance. Knowing the reason of the change, the provision in its new wording is interpreted in such a way that the norm resulting therefrom was devoid of flaws or weaknesses, which manifested themselves during the application of the provision in its previous form. This conception of interpretation may raise doubts, however, the final form of the norm is determined in this situation not by what the legislator did but what, according to the interpreter, he intended to do. (Brzeziński, 2001, p. 166). The aforesaid question was reflected in the decision of NSA (wyrok NSA z dnia 18 października 1995, SA/Gd 2062/94), where the Court recognised that the interpretation which on the basis of analogiae legis to the subsequent provision allows for the interpretation of the previous provision is by no means justified, since analogy in tax law is unacceptable. This opinion should not be considered as completely accurate, for example for the fact that analogy in tax law is acceptable in certain cases, and sometimes even necessary. Also in judicial decisions there is a great number of examples of using historical interpretation by judges. The decision of NSA (wyrok NSA z dnia 28 listopada 1996, SA/Ka 2006/95) outlined the direction of changes in provisions, as a significant element for their interpretation. On the other hand, the same Court, in the statement of reasons of the decision of NSA (wyrok NSA z dnia 14 marca 1994, III SA 1794/93) stated that using historical interpretation is a commonly acceptable form of interpretation of law on condition that it does not lead to the views contradictory to the wording of law. Unless grammatical interpretation gives an unequivocal answer as to the wording of the law, it is an advantage, and not a mistake, of the interpretation to reach for arguments resulting from the evolution of legal regulations concerning a certain problem. 
Thus, it is important to admit that historical interpretation may be useful in the process aiming at the establishment of the meaning of a particular provision of tax law. It should never, however, be treated independently, isolated from the other methods of interpretation, but should constitute the subsequent, the last stage of interpretation. A good example confirming the aforesaid thesis is the decision of TK (wyrok TK z dnia 6 września 1995, W.20/94) concerning the interpretation of Article 2 point 1 of the Act on Local Taxes and Fees (ustawa z dnia 12 stycznia 1994 r. o podatkach i opłatach lokalnych (Dz. U. z 1991 Nr 9, poz. 31)) in which the Tribunal explained what premises should make up the basis for establishing a taxpayer by a tax organ from among the owner or possessor of a property or a civil structure not permanently fixed with the ground, at determining the property tax. After linguistic, systemic and purposive interpretations, the Tribunal reached for historical interpretation and decided that "(...) also historical interpretation leads to the conclusion that in the property tax the taxpayer is the person who really owns the land. (...). Using historical interpretation it is foremost important to bear in mind the solutions of the first years after the war, made with an assumption that property tax is a municipal tax, and the person actually owning the property profits from this title. (...) Both systemic interpretation in compliance with constitutional provisions and other provisions of the Act of 12 January 1991 (ustawa z dnia 12 stycznia 1991 - o podatkach i opłatach lokalnych (Dz. U. z $1991 \mathrm{Nr}$ 9. poz 31)), as well as purposive and historical interpretation lead to the assumption that in the situation where the autonomous possessor of the property is not its owner, the tax liability provided for in Article 2 point 1 of the Act of 12 January 1991 rests on the autonomous possessor. The tax organ cannot discretely select the taxpayer."

\section{The economic method of tax law interpretation}

A type of purposive interpretation is the so-called economic method of considering tax law. This type of interpretation is especially widespread in the countries of the German legal tradition (Germany, Austria, Switzerland), as well as in American and British law, where its counterpart is the principle substance over form. In accordance with the views of German authors the economic method of considering tax law narrows down to the establishment if the notion in a tax provision, which is simultaneously a notion of civil law, should not be attributed with an economic meaning, which is different from its meaning under civil law. (Tipke, Lang, 1991, p. 101). 


\section{Rafat Dowgier}

The doctrine substance over form, on the other hand, is characterised in the following way (Brzeziński, 1996, p. 24): "This doctrine, assessing its tax and legal effects, assumes priority of the substance of a legal action over the form in which the action was performed. This doctrine is based on an assumption that the economic result of a particular action is its essence. The form in which the action is performed, on the other hand, is a secondary circumstance. Consequently, in the situations where a taxpayer chooses forms convenient in terms of tax - if these forms mask such economic occurrences which should be taxed - the substance should be a priority and taxation should be applied."

In the Polish tax law system the above-presented conception is reflected in Article 199a of the Tax Ordinance Act (ustawa z dnia 29 sierpnia $1997 \mathrm{r}$. - Ordynacja podatkowa, Dz. U. 2012, poz. 749 j.t.). On the basis of this provision tax organs were granted authorisation to establish the substance of a legal action in compliance with the consistent intention of the parties and the purpose of this action, and not only on the basis of the literary wording of the intention statements submitted by the parties. If under the guise of a legal action another legal action was performed, the tax effects are derived from this implicit legal action (Article 199a $§ 2$ Tax Ordinance Act). (Dz. U. 2012 , poz. 749 j.t.). This regulation is a response to the views concerning the interpretation of contractual provisions in the aspect of their tax and legal effects, which occurred in judicial decisions of courts much earlier. Especially in the decision of the Supreme Court (wyrok Sądu Najwyższego z dnia 3 września 1998, CKN 815/97) expressed an opinion that "the interpretation of the provision of an agreement, semantically vague, cannot be based on the linguistic analysis of the relevant part of the agreement only but it is also necessary to examine the intention and the purpose of the parties, as well as the actual context in which the contract was agreed upon and signed. It is impossible to do it without interrogating the people directly involved, or possibly taking into consideration substantive circumstances, such as, essential in economic relations, rules and customs of cooperation, both between the parties as well as in the contracts of the parties with other people."

In the content of Article 199a of the Tax Ordinance Act (Dz. U. 2012, poz. 749 j.t.) we can attempt to find elements of the principle of economic interpretation of law. This interpretation aims at the interpretation of law from the point of view of economic reality, clearly distinguishing the substance from the civil law form of legal actions. The emphasis is put on the real substance of these actions and not their external form. (wyrok Naczelnego Sądu Administracyjnego z dnia 14 grudnia 2004, FSK 826/04). 
It is indicated that the economic interpretation is connected, on the one hand, with the problems of adequacy of commercial exchange actions and the forms in which they are performed, and on the other hand, with the substance of the economic actions which are concerned with these behaviours and expressed by the forms. (Pietrasz, 2011, p. 971). Applying the forms of exchange, more or less adequate to the economic substance of economic occurrences is not a subject of interest either on the part of the legislator, or the tax administration until it leads to lowering the tax liability below the level considered adequate. (Brzeziński, 2008, p. 151 and next).

\section{Purposive interpretation directives}

The theory of law developed several directives of functional interpretation, which may be also referred to as purposive interpretation. Selecting them for their usefulness for the needs of tax law, the following directives of purposive interpretation can be distinguished:

- Interpreting a norm, we should take into consideration social and economic consequences to which a certain interpretation will lead and choose such interpretation which leads to the most favourable consequences

The aforementioned directive is of considerable importance in tax law because it is expected to fulfil several provisions, such as the fiscal function and also social functions. A good example of this is the statement of reasons of the decision of NSA (wyrok NSA z dnia 26 sierpnia 1998, I SA/Wr 1980/96) on the possibility of acquiring the reduction defined in Article 16 of the Act on Tax on Inheritance an Donations (ustawa z dnia 28 lipca 1983 r. o podatku od spadków i darowizn (Dz. U. z $1983 \mathrm{Nr}$ 45, poz. 207 z późn. zm.)). In the statement of reasons for this decision the Court stated: "The provision of Article 16 of the Act of 28 July 1983 on Tax on Inheritance and Donations establishes a housing reduction for the persons who acquire, through inheritance or donation, a flat, a house or its part. The reduction involves exempting from the tax base their value up to the combined amount not exceeding 110 square meters of the usable area of the building or premises. The objective of this regulation is not charging the donator or the testator's close and closest persons with financially considerable tax effects due to the material profit in the form of the aforementioned property, when they do not have a building or a flat at their disposal and intend to reside 


\section{Rafat Dowgier}

in the premises or the building acquired for 5 years or sell them in order to make a necessary change of housing conditions. Legal norms included in these regulations are undoubtedly norms of a community purpose directed to implementing the state's policy in guaranteeing citizens decent housing standards. Thus, interpreting this regulation tax organs should pursue not only linguistic interpretation but also purposive interpretation, proceeding in such a way that the interpretation applied does not result in inability to implement the assumed end of the legal norm."

- Interpreting legal provisions we should take into consideration the purpose of the legal regulation (ratio legis).

In the case of the above-mentioned directive it is important to assume that the actions of the legislator are purposive actions serving to achieve certain ends. They do not have to be social ends. Frequently the only purpose of a particular regulation is securing incomes for the budget, i.e. a fiscal aim. Therefore the interpretation should be carried out not only in the context of social effects, to which it actually leads, but also in the context of other effects, which the legislator wanted to achieve.

- Legal provisions should be interpreted in accordance with the will of the historical legislator, referring to the rights of the current legislator only to a limited degree.

In the interpretation of tax law we should, however, opt for the domination of the static theory of interpretation because of the dominant role of the principle of certainty of law. Particularly the tax and legal scope of the actual state should result from the act of law and be unchangeable, in accordance with the legislator's intention. Exceptions in favour of the dynamic theory are possible, and from the point of view of taxpayers desirable, in reference to tax reductions and exemptions. In this case it is rather the end these institutions are to pursue that is decisive than the very, vague, wording of the provisions of the act.

- If we take into consideration the aims, values and extra-legal rules in establishing the meaning of the legal rule interpreted, they should be equally taken into consideration in relation to all the rules of which the institution is composed, to which the rule interpreted appertains.

This directive demands consistency in purposive interpretation - if a particular institution is to achieve a certain end, then all regulations constituting it should be interpreted in compliance with this end. 


\section{Conclusions}

The above considerations allow for posit a thesis according to which purposive interpretation is an indispensable element of the process of interpreting a legal text. Its role in the scope of norms of tax law is, however, peculiar, since it serves only to verify the results of linguistic interpretation. The primacy of linguistic interpretation stems from Articles 84 and 217 of the Constitution of the Republic of Poland (Dz. U. z 1997 Nr 78, poz. 483), which reserves the obligation of bearing public burdens, as well as determining their components for an act of law. Such acts, as well as other legal texts, should be interpreted with the commonly applied rules of interpretation. Thus, adopting the derivative conception of law interpretation, it is important to recognise that it is recommendable to apply also non-linguistic methods of interpretation. In this context purposive interpretation becomes especially important, which foremost allows us to eliminate the doubts connected with the ambiguity of a legal text, referring to the end which the legal rule is supposed to pursue.

A particular aspect of applying purposive rules of interpretation, currently emphasised in the literature, is raising the rule in dubio pro tributario to the status of a tax law rule. Such a high distinction of this rule may be disputed, of course, which does not change the fact that it has long been noticeable in interpreting tax law regulations.

In conclusion, we can posit a thesis that the growth in importance of purposive interpretation is directly proportional to the fall in the quality of tax law regulations. Taking into consideration the legislative experience of recent years, it does not seem that this state of affairs will change soon.

\section{N O T E S}

1 This problem is widely perceived by the literature: compare: Mastalski, R. (1989, p. 108), Smoktunowicz, Mieszkowski (1998, p. 129).

2 It seems that this thesis finds its confirmation in judicial decisions: compare, for example, the wyrok NSA z dnia 1 marca 2000 (I SA/Wr 2915/98), Monitor Podatkowy $(2000,11)$, where the Court interpreting the term "renovation" stated that using the dynamic interpretation with the word "renovation", we should take into consideration the changing economic reality and technological progress, which influence the method and the means of the works included in this term.

${ }^{3}$ In the question of qualifying historical interpretation as a particular variation of purposive interpretation there may occur certain doubts for an analysis of judicial decisions leads to the conclusion that these two types of interpretation are clearly different from each other. However, bearing in mind that the element of purpose connects them, the paper assumes that their mutual connection is reasonable. 


\section{R E F E R E N C E S}

Brzeziński, B. (1996). Anglosaskie doktryny orzecznicze dotyczace unikania opodatkowania. Toruń: Uniwersytet Mikołaja Kopernika, 24.

Brzeziński, B. (2001). Wstęp do nauki prawa podatkowego. Toruń: TNOiK "Dom Organizatora", 164.

Brzeziński, B. (2008). Podstawy wykładni prawa podatkowego. Gdańsk: Ośrodek Doradztwa i Szkolenia Kadr, 151 and next.

Brzeziński, B. (2008). Wprowadzenie do prawa podatkowego. Toruń: TNOiK "Dom Organizatora", 281.

Gizbert-Studnicki, T. (1996). Wykładnia celowościowa. Studia Prawnicze, 3-4.

Konstytucja Rzeczpospolitej Polskiej z dnia 2 kwietnia 1997 (Dz. U. z 1997 Nr 78, poz. 483).

Mariański, A. (2009). Rozstrzyganie watpliwości na korzyść podatnika. Zasada prawa podatkowego. Warszawa: Wolters Kluwer.

Mastalski R. (1989). Interpretacja prawa podatkowego. Źródta prawa podatkowego i jego wyktadnia. Wrocław: Wydawnictwo Uniwersytetu Wrocławskiego, 108.

Mastalski, R. (1998). Prawo podatkowe I - cześć ogólna. Warszawa: C. H. Beck, 97.

Pietrasz, P. (2011). In Cezary Kosikowski et al., Ordynacja podatkowa. Komentarz, edition 4, (p. 971). Warszawa: Wolters Kluwer.

Smoktunowicz, E., Mieszkowski, J. (1998). Źródła i wykładnia prawa podatkowego. Białystok: Prawo i praktyka gospodarcza, 78.

Tipke, K., Lang, J. (1991). Steuerrecht, ed. 13. Köln: Verlag Otto Schmidt, 101.

Ustawa z dnia 12 stycznia 1994 r. o podatkach i opłatach lokalnych (Dz. U. z 1991 Nr 9, poz. 31).

Ustawa z dnia 14 czerwca 1960 r. - Kodeks postępowania administracyjnego (Dz. U. Nr 2013, poz. 267 j.t.).

Ustawa z dnia 28 lipca 1983 r. o podatku od spadków i darowizn (Dz. U. z 1983 Nr 45, poz. 207 z późn. zm.).

Ustawa z dnia 29 sierpnia 1997 r. - Ordynacja podatkowa (Dz. U. z 2012, poz. 749 j.t.).

Wyrok Naczelnego Sądu Administracyjnego z 19 maja 1998, III SA 1594/96, LEX nr 37119.

Wyrok Naczelnego Sądu Administracyjnego z dnia 1 marca 2000, I SA/Wr 2915/98, Monitor Podatkowy (2000), 11.

Wyrok Naczelnego Sądu Administracyjnego z dnia 1 marca 2000, I SA/Wr 1980/96, ONSA, 1999, poz. 2.

Wyrok Naczelnego Sądu Administracyjnego z dnia 14 marca 1994, III SA 1794/93, Monitor Podatkowy (1995), 2.

Wyrok Naczelnego Sądu Administracyjnego z dnia 14 grudnia 2004, FSK 826/04, LEX nr 147675. 
Wyrok Naczelnego Sądu Administracyjnego z dnia 18 października 1995, SA/Gd 2062/94, Przeglad Orzecznictwa Podatkowego, 2000, 4.

Wyrok Naczelnego Sądu Administracyjnego z dnia 23 czerwca 1983, II SA 535/83, Orzecznictwo Sądów Polskich 1983, nr 12, poz. 272.

Wyrok Naczelnego Sądu Administracyjnego z dnia 28 listopada 1996, SA/Ka 2006/95, LEX nr 27392.

Wyrok Naczelnego Sądu Administracyjnego z dnia 7 października 1992, SA/Po 1167/92, Wspólnota, 1993, 40.

Wyrok Naczelnego Sądu Administracyjnego, z dnia 6 listopada 1996, SA/Ka 1895/95, ONSA, 1997, nr 4.

Wyrok NSA z dnia 1 marca 2000 (I SA/Wr 2915/98), Monitor Podatkowy, 2000, 11.

Wyrok Sądu Najwyższego z 2 października 1987, sygn. akt AZP 6/87, Przeglad Ustawodawstwa Gospodarczego, 1988, 5-6.

Wyrok Sądu Najwyższego z dnia 22 października 1992, III ARN 50/92, Przegląd Orzecznictwa Podatkowego, 1994, 2.

Wyrok Sądu Najwyższego z dnia 3 września 1998, I CKN 815/97, OSNC 1999, nr 2, poz. 38.

Wyrok Trybunału Konstytucyjnego z dnia 20 lutego 1991, W. 5/90, OTK 1991, poz. 193.

Wyrok Trybunału Konstytucyjnego z dnia 26 marca 1996, W. 13/95, OTK 1996, poz. 2.

Wyrok Trybunału Konstytucyjnego z dnia 6 września 1995, W. 20/94, OTK 1995, poz. 1. 